\title{
Adrenomedullin Inhibits Choroidal Neovascularization via CCL2 in the Retinal Pigment Epithelium
}

\author{
Kentaro Yuda, ${ }^{*}$ Hidenori Takahashi, ${ }^{*}$ \\ Tatsuya Inoue, ${ }^{*}$ Takashi Ueta, ${ }^{*}$ Aya Iriyama, \\ Kazuaki Kadonosono, ${ }^{* \dagger}$ Yasuhiro Tamaki, ${ }^{*}$ \\ Hiroyuki Aburatani, ${ }^{\ddagger}$ Ryozo Nagai, ${ }^{\S}$ and \\ Yasuo Yanagi* \\ From the Departments of Ophthalmology, and Cardiovascular \\ Medicine, University of Tokyo School of Medicine, Tokyo; the \\ Department of Ophthalmology, ${ }^{\dagger}$ Yokohama City University \\ Medical Center, Yokohama; and the Genome Science Division, ${ }^{\neq}$ \\ Research Center for Advanced Science and Technology, \\ University of Tokyo, Tokyo, Japan
}

The molecular mechanism that leads to age-related macular degeneration (AMD) is poorly understood. Gene expression profiling identified adrenomedullin $(A D M)$ as a possible molecular target for the treatment of AMD and expression of $A D M$ was upregulated in eyes with laser-induced choroidal neovascularization (CNV). In vivo experiments strongly indicated that ADM inhibits laser-induced CNV. In vitro tube formation assay demonstrated that neither ADM nor conditioned medium from the retinal pigment epithelial (RPE) cells, D407 cells, treated with ADM affected the capillary-formation of human umbilical vein endothelial cells. In contrast, in vitro macrophage migration assay clearly demonstrated that the conditioned medium of $\mathrm{D} 407$ inhibited macrophage migration. Furthermore, the expression of $\mathrm{C}-\mathrm{C}$ motif chemokine 2 (CCL2) was significantly inhibited in $\mathbf{D 4 0 7}$ cells after ADM treatment. In vivo experiments using a laserinduced $\mathrm{CNV}$ model in $\mathrm{ADM}^{+/-}$mice demonstrated that CCL2 expression was upregulated in $\mathrm{ADM}^{+/-}$ mice with concomitant increase in macrophage migration in the subretinal space. Additionally, the effect of ADM was abrogated in CCL2 knockout mice. These results suggest that administration of ADM inhibits macrophage migration in the subretinal space and leads to the suppression of laser-induced $\mathrm{CNV}$ in an animal model. The inhibition of macrophage migration occurred through the CCL2 from RPE. This study provides a novel potential therapeutic target for AMD which does not substantially disrupt VEGF-A signaling mediated vasculogenesis. (Am J Pathol 2012, 181:14641472; http://dx.doi.org/10.1016/j.ajpath.2012.06.028)

Choroidal neovascularization (CNV) in age-related macular degeneration (AMD) is the leading cause of blindness in people over 50 years of age. ${ }^{1,2}$ AMD is characterized by progressive degeneration of the retina, retinal pigment epithelium (RPE), and underlying choroid. The earliest clinical hallmark of AMD is the appearance of drusen, localized lipoproteinaceous deposits between the RPE, and Bruch membrane. ${ }^{3}$ Drusen and RPE dysfunction are implicated in CNV formation. ${ }^{4} \mathrm{~A}$ body of evidence suggests that injury to the RPE plays a role in drusen biogenesis. ${ }^{5,6}$ This injury is considered to occur through gene mutations, light damage, oxidative stress, and lipofuscin accumulation, and results in the release of cytokines into the Bruch membrane. ${ }^{7-13}$ Some of the chemokines diffuse into the choroid and work for monocytes, and these inflammatory cells amplify the local inflammatory cycle by mechanisms including immune complex formation and complement activation. ${ }^{14-18}$ Thus, chronic inflammation is an important process in drusen biogenesis. Previous studies have shown that C3 and membrane attack complex (MAC) deposit in CNV lesions. It has also been reported that the accumulation of complement component can induce vascular endothelial growth factor (VEGF) in RPE and contribute to CNV formation. ${ }^{17,19}$ The factors involved in this chronic inflammatory process are therefore potential therapeutic targets of AMD.

Early epidemiological studies have established that the disease is heritable and clearly modulated by nongenetic environmental risk factors ${ }^{20,21}$, whereas biochemical and histological studies have demonstrated that the complement system was involved in drusen biogenesis

Supported in part by a grant-in-aid from the Ministry of Education, Science, Sports and Culture of Japan (grant 21592217)

Accepted for publication June 28, 2012

Supplemental material for this article can be found at http://ajp. amjapathol.org or at $h t t p: / / d x . d o i . o r g / 10.1016 /$ j.ajpath.2012.06.028.

Address reprint requests to Yasuo Yanagi, M.D., Ph.D., Department of Ophthalmology, University of Tokyo School of Medicine, 7-3-1 Hongo, Bunkyo-ku, Tokyo 113-8655, Japan. E-mail: yanagi-tky@umin.ac.jp. 
and the etiology of $\mathrm{AMD} .{ }^{18}$ One of these genes, complement factor $\mathrm{H}(\mathrm{CFH})$ on chromosome $1 \mathrm{q} 32$ has been identified by a number of studies as a major AMD-susceptible gene polymorphism. ${ }^{22-26}$ In addition, biochemical and pathological studies have shown that a $\mathrm{CFH} \mathrm{Y402H} \mathrm{poly-}$ morphism may be involved in AMD. ${ }^{27,28}$ Some studies have suggested that RPE and choroidal cells may have the capacity to synthesize a number of these complement-regulatory molecules. ${ }^{12,29-32}$ If these cells synthesize significant quantities of complement component molecules and the associating factors, they could make a substantial contribution to the pathogenesis of AMD.

Evidence supports a role for VEGF in CNV. ${ }^{33}$ Of the subtypes of VEGF, VEGF-A has become a major therapeutic target for CNV ${ }^{34}$ Blockage of VEGF-A signaling led to the remarkable recovery of visual acuity in neovascular AMD patients ${ }^{35-37}$; however, it should be noted that receptors for VEGF-A are present in normal retinal neuronal cells and that VEGF-A provides neuroprotection in the retina. ${ }^{38}$ Under certain pathological conditions, such as the development of CNV and retinal neovascularization in the eye or in cancerous tumor development, angiogenesis is considered to be an adverse phenomenon. ${ }^{39-41} \mathrm{It}$ is therefore a concern that even if blocking VEGF-A signaling is effective in suppressing CNV development, the continuous blocking of VEGF-A signaling in these agents may in fact be dangerous to patients, particularly those of advanced age, such as AMD patients. ${ }^{38,42-48}$ Moreover, some AMD patients are refractory to current anti-VEGF therapies. ${ }^{37,49}$ Thus, treatment strategies based on more specific targeting of CNV are desirable.

In the present study, using aged mice and mice with laser-induced CNV, the expression of complement components and their associating factors in the RPE/choroid were examined, especially focusing on factors associated with $\mathrm{CFH}$ using microarray analysis. Among these factors, adrenomedullin (ADM) was found to be remarkably upregulated in the RPE/choroidal layer after laser treatments. This result led us to investigate the effects of $\mathrm{ADM}$ on the development of CNV.

\section{Materials and Methods}

\section{Animals}

Male 6- to 8-week old mice or 18-month old mice as the aged mice were used in all experiments. ADM homozygous knockout have an embryonic lethal phenotype with abnormal vascular development; the study used $A D M$ knockout $\left(\mathrm{ADM}^{+/-}\right)$mice on a C57BL/6 background kept as a heterozygous line, in which decreased expression of ADM has been confirmed. ${ }^{50}$ C57BL/6 mice were purchased from CLEA Japan (Tokyo, Japan), and CCL2 knockout $\left(C C 2^{-I-}\right)$ mice were purchased from Jackson Laboratory (Bar Harbor, ME). All experiments were conducted in accordance with the Animal Care and Use Committee, and the Association for Research in Vision and Ophthalmology Statement for the use of Animals in Ophthalmic and Vision Research.

\section{Cell Culture}

Human retinal pigment epithelial cells, D407, and RAW264.7 macrophage cells were maintained in Dulbecco's modified Eagle's medium (DMEM) with $10 \%$ fetal bovine serum, $100 \mathrm{U} / \mathrm{mL}$ of penicillin, and $10 \mu \mathrm{g} / \mathrm{mL}$ of streptomycin. Human umbilical vein endothelial cells (HUVECs) were maintained in Medium 200 supplemented with Low Serum Growth Supplement kit. These cells were incubated at $37^{\circ} \mathrm{C}$ in a humidified $5 \% \mathrm{CO}_{2}$ incubator.

ADM was delivered at concentrations of $10^{-7}, 10^{-8}$, and $10^{-9} \mathrm{M}$ into the culture media, and confluent cultures of the RPE cells were incubated with ADM. After 12 hours, cells were collected and used for mRNA quantification by real-time reverse transcription-PCR (RT-PCR). The conditioned medium was collected for in vitro tube formation assay and macrophage migration assay.

\section{Experimental CNV}

General anesthesia was induced with an intraperitoneal injection of a mixture (5:1) of ketamine hydrochloride (Ketalar, Sankyo, Tokyo, Japan) and xylazine hydrochloride (Celctal, Bayer, Tokyo, Japan). The pupil was dilated with 1 drop of $0.5 \%$ tropicamide and $0.5 \%$ phenylephrine (Mydrine P, Santen Pharmaceutical, Osaka, Japan) for photocoagulation. Experimental CNV was created as has been described elsewhere. ${ }^{51}$ Laser photocoagulations were applied to each eye between the major retinal vessels around the optic disk with a diode laser photocoagulator (DC-3000, NIDEK, Osaka, Japan) and a slit lamp delivery system (SL 150, Topcon, Tokyo, Japan) at a spot size of $75 \mu \mathrm{m}$, duration of 0.05 seconds, and intensity of $200 \mathrm{~mW}$. An attempt was made to break the Bruch membrane, as evidenced by the central bubble formation. Immediately after the photocoagulation, $1 \mu \mathrm{L}$ of $\mathrm{ADM}$ $\left(10^{-7} \mathrm{M}\right)$ or PBS was injected into the vitreous cavity.

\section{Microarray Analysis}

Male 6- to 8-week-old mice and 18-month-old mice were used for microarray analysis. Seven days after laser treatment, mRNA from RPE/choroidal was isolated using RNeasy Mini kit (Qiagen, Valencia, CA). Target RNA was hybridized on a GeneChip Mouse Genome 4302.0 array (Affymetrix, Santa Clara, CA) at the research Center for Advanced Science and Technology, University of Tokyo. The experimental procedures for the GeneChip were performed according to the Affymetrix technical manual. Two paired sets of samples from individual eyes were used for analysis.

\section{Fluorescein Angiography}

Seven days after the laser treatment, the mice were intraperitoneally anesthetized. Fluorescein angiography was performed to quantify the amount of leakage from the CNV, as previously described. ${ }^{51}$ Four to 6 minutes after the injection, three angiograms were taken using a retinal camera (TRC-50IX, Topcon), with the built-in filter for fluorescein. The images were captured with a $3 C C D$ color video camera $(640 \times 480$ pixels) $(\mathrm{DXC970MD}, \mathrm{SONY}$, Tokyo, Japan), 
imported into a Windows personal computer, and analyzed using ImageJ software version $1.46(\mathrm{NIH}$, Bethesda, MD). The signal intensities (brightness) within the leakage from CNV were measured and integrated at each lasered site.

\section{Fluorescein Isothiocyanate Dextran Angiography and Flat Mount}

Mice were perfused with $1 \mathrm{~mL}$ of PBS containing 50 $\mathrm{mg} / \mathrm{mL}$ of fluorescein-labeled dextran from the left ventricle for 1 minute, followed by removal of the eyes. After the eyes were enucleated and briefly fixed in 4\% PFA, the anterior segment and neural retina were carefully removed. Four to six radial cuts were made from the edge to the equator, and the eye cup was flat mounted with the sclera facing down. Using the appropriate FITC filters, the flat mounts were viewed under an epifluorescent microscope. A computer-operated digital camera with image capture (Olympus BX51, Olympus, Tokyo, Japan) was used to photograph the areas of choroidal neovascularization. The total area of hyperfluorescence was measured using ImageJ software.

\section{Terminal Deoxynucleotidyl Transferase- Mediated dUTP Nick End-Label Staining}

Apoptotic cell death was judged by terminal deoxynucleotidyl transferase-mediated dUTP nick end-label (TUNEL) staining, which was performed using a kit (DeadEnd Fluorometric TUNEL System), according to the manufacturer's instructions (Promega, Madison, WI). The apoptotic cells were visualized with fluorescein-12-dUTP, and nuclei were stained with propidium iodide $(\mathrm{PI})$. For positive controls, sections were processed with DNase I (Takara Bio, Tokyo, Japan).

\section{Immunostaining and Transmission Electron Microscopy}

Immunostaining was performed as has been described previously. ${ }^{52}$ Briefly, after the RPE-choroidal flat mount was made, the sample was incubated with rat anti-mouse F4/80 antibody. Alexa 488-conjugated secondary antibody was used to visualize the immunostaining. The immunostained flat mounts were viewed in five fields at $\times 200$ magnification, and F4/80-positive cells around CNV were counted for investigating the macrophage infiltration toward CNV.

Transmission electron microscopy was performed by Hanaichi Ultrastructure Research Institute Co. (Okazaki, Japan) with reference to the previous report. ${ }^{53}$ Eyes were fixed with $2 \%$ paraformaldehyde and $2 \%$ glutaradehyde in $0.1 \mathrm{M}$ PBS at pH7.4, and semithin sections were analyzed using an electron microscope (JEOL JEM-200EX, Akishima, Japan).

\section{Histological Analysis}

Eyes were enucleated and embedded in paraffin blocks, and $7-\mu \mathrm{m}$ semithin sections were made. The sections were mounted on glass slides and stained with $\mathrm{H} \& \mathrm{E}$.

\section{In Situ RT-PCR}

Immediately after enucleation, eyes were fixed in $4 \%$ paraformaldehyde in PBS for 1 hour. The eyes were embedded in optimum cutting temperature compound (Tissue-Tek, Torrance, CA) and cut into 7- $\mu \mathrm{m}$ sections. In situ RT-PCR was performed with the sections covered by a slide seal (Takara Bio, Tokyo, Japan) and using a thermal cycler equipped with a unit for in situ PCR (DNAEngine; BioRad). After reverse transcription (RT), PCR was performed in the presence of $1 \mathrm{mM}$ DIG-11-dUTP (Roche Diagnostics, Basel, Switzerland) using ADM-specific primers. Development of the sections was performed following the protocols of the manufacturer and as has been previously described. ${ }^{54}$

\section{mRNA Quantification by Real-Time RT-PCR}

mRNA for RT-PCR was isolated using SV Total RNA Isolatin Kit (Promega, Madison, WI) in accordance with the manufacturer's instructions. cDNA was prepared using Superscript III for RT-PCR (Invitrogen, Carlsbad, CA). Each PCR was carried out in a $20-\mu \mathrm{L}$ volume using Platinum SYBR Green qPCR SuperMix UDG (Invitrogen) for 30 seconds at $95^{\circ} \mathrm{C}$ denature, followed by 55 cycles at $95^{\circ} \mathrm{C}$ for 5 seconds, $55^{\circ} \mathrm{C}$ for 5 seconds, and $72^{\circ} \mathrm{C}$ for 10 seconds in a Roche LightCycler. Values for each gene were normalized to expression levels of GAPDH. The sequences of the primers used for RT-PCR were as follows:

Human GAPDH, left, 5'-GAGTCAACGGATTTGGTCGT-3', right, 5'-TTGATTTTGGAGGGATCTCG-3'; mouse GAPDH, left, 5'-CACATTGGGGGTAGGAACAC-3', right, 5'-AACTTTGGCATTGTGGAAGG-3'; human VEGF-A, left, 5'-ATGTGCATGGTGATGTTGGA-3, right, 5'-GCTTGCTGCTGTACCTCCAC-3'; human VEGF-B, left, 5'-CCCTTGACTGTGGAGCTCAT-3', right, 5'-CACTGGCTGTGTTCTTCCAG-3'; human CCL2, left, 5'-CAGCCAGATGCAATCAATGC-3', right, 5'-GTGGTCCATGGAATCCTGAA-3'; mouse CCL2, left, 5'-CAGGTCCCTGTCATGCTTCT-3', right 5'-TCTGGACCCATTCCTTCTTG-3'; human CCL11, left, 5'-CCCTTCAGCGACTAGAGAGC-3', right, 5'-TGGCTTTGGAGTTGGAGATT-3'; human CCL24, left, 5'-GCCTTCTGTTCCTTGGTGTC-3', right, 5'-TGTACCTCTGGACCCACTCC-3'; human CCL26, left, 5'-CTGCTTCCAATACAGCCACA-3', right, 5'-CACAATTGTTTCGGAGTTTTCA-3'; mouse Adrenomedullin, left, 5'-TTCGCAGTTCCGAAAGAAGT-3', and right 5'-CCATGGGTGTTCTGCTCGTC-3'.

\section{In Vitro Tube Formation Assay}

In vitro angiogenesis activity was evaluated with the in vitro tube formation assay. Human umbilical vein endothelial cells (HUVECs) starved of serum for 4 hours were seeded at a cell density of 40,000 cells per well in 24-well culture plates (Nalge Nunc International), precoated with $0.4 \mathrm{~mL}$ of low-growth factor synthetic matrix (Matrigel, BD Bioscience, San Jose, CA) and cultured with the conditioned medium (DMEM) collected from D407 cells or D407 cells exposed to ADM for 24 hours. Tube formation was determined 16 hours after cells were plated on Matrigel by counting the number of connected cells in five 
randomly selected fields at $\times 200$ magnification, and dividing that number by the total number of cells in the same field. Micrographs were taken under a phase-contrast light microscope (Olympus, Tokyo, Japan).

\section{In Vitro Migration Assay}

Transwell migration assays were performed using a modification of the 96-well microchemotaxis assay, as has been described. ${ }^{55,56}$ RAW264.7 cells $\left(5 \times 10^{4}\right.$ cells) were loaded onto the top wells of the chamber (Corning Costar, Cambridge, MA) with conditioned medium (DMEM), collected from D407 cells or D407 cells exposed to ADM for 24 hours in the bottom chamber and incubated for 6 hours. Cells on the lower surface of the filter were fixed with $4 \%$ paraformaldehyde in PBS for 10 minutes at room temperature and stained with H\&E staining. The transmigrated cells were photographed in triplicate at $\times 40$ magnification. Cell migration was determined as the number of cells that had migrated across the filter in the photographed area.

\section{Statistical Analysis}

All results are presented as the mean ( \pm SEM). The nested analysis of variance test was performed to assess the CNV area. Tube formation assay, macrophage migration assay, and RT-PCR were assessed using the Student $t$-test. Values of $P<0.05$ were taken as statistically significant. Statistical analysis was performed with the SPSS 17.0 program for Windows (SPSS Inc., Chicago, IL).

\section{Results}

\section{Increased ADM Expression in RPE/Choroid and Retina with Laser-Induced CNV}

To investigate whether there was any role of complement pathway molecules in the pathogenesis of AMD, aged mice and laser-induced CNV model mice, the most widely used animal model of this disease, were used. The results demonstrated that at the mRNA (mRNA) level, the complement pathway proteins such as $\mathrm{C} 1 \mathrm{q}, \mathrm{C} 3$, and $\mathrm{C} 4$ are upregulated in RPE/choroid in CNV model mice, and these results are consistent with previous reports (see Supplemental Table S1 at $h$ ttp://ajp.amjpathol.org). ${ }^{17,19}$ It was confirmed that $\mathrm{C} 3$ is also upregulated in aged mice. The relative abundances of these mRNAs in the RPE/ choroid support the theory that local cells have the potential to make a substantial contribution to CNV.

Expression of factors that regulate $\mathrm{CFH}$ or bind with $\mathrm{CFH}$ and have coactivity was also investigated. It is known that $\mathrm{C}$-reactive protein (CRP), fibromodulin, and $\mathrm{ADM}$ bind with $\mathrm{CFH} .{ }^{57}$ Of these genes, interest was focused on ADM because the expression level was increased in the RPE/choroidal layer of laser-induced CNV model mice (see Supplemental Table S1 at $h$ ttp://ajp. amjpathol.org).

Real-time RT-PCR demonstrated that the expression of ADM was increased 1.57-fold in the RPE/choroid layer and 1.87 -fold in the retina after laser treatment, in comparison to
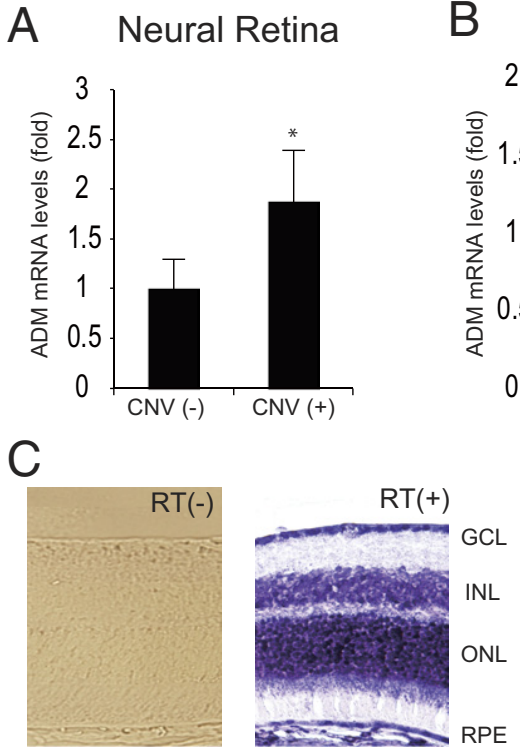

Figure 1. Expression pattern of ADM mRNA in the retina and the RPE/ choroid layer. Real-time RT-PCR demonstrated that after laser treatment, the expression of ADM was increased 1.87-fold in the retina (A) and 1.57-fold in the RPE/choroid layer (B), respectively, in comparison to non-photocoagulation mice. $n=8$ for all. ${ }^{*} P<0.05$. C and D: In situ RT-PCR analysis in albino mouse and laser-induced CNV model mouse. Normal retina expressed detectable levels of ADM in the ganglion cell layer, inner and outer nuclear layer, endothelial cells, and retinal pigment epithelial cells (C). ADM mRNA was also detected in the laser-induced CNVs in mice, most prominently in highly vascularized lesions and also in stromal cells and retinal pigment epithelial cells (D)

non-photocoagulation mice (Figure 1, A and B). The expression pattern of ADM mRNA was examined with in situ RT-PCR in normal retina and 7 days after laser treatment. Under physiological conditions, normal retina expressed detectable levels of ADM in the ganglion cell layer, inner and outer nuclear layer, endothelial cells, and retinal pigment epithelial cells (Figure 1C). ADM mRNA was also detected in the laser-induced CNVs in mice, most prominently in highly vascularized lesions and also in stromal cells and retinal pigment epithelial cells (Figure 1D).

\section{Increased CNV Lesions in $\mathrm{ADM}^{+/-}$Mice}

To evaluate the effect of ADM on CNV, eyes from $\mathrm{ADM}^{+/-}$ mice and age-matched wild-type mice were subjected to laser-induced CNV. The retinal structure, retinal vessels, and structure of RPE/choroid of $A D M^{+/-}$mice were normal as examined by light microscopic analysis, TUNEL staining, flat mount analysis, and transmission electron microscopic analysis (see Supplemental Figure S1 at http://ajp.amjpathol.org). Interestingly, $A D M^{+/-}$mice showed significant increase in leakage from CNV compared with control mice (Figure 2, A and B). To confirm whether the increase in leakage in fluorescein angiography is actually a consequence of the CNV lesions, the CNV lesions were analyzed by choroidal flat mounts, which demonstrated that the CNV lesions in $\mathrm{ADM}^{+/-}$mice were significantly larger than those in wild-type mice (Figure 2, C and D). In addition, the effects of intraocular ADM administration were examined after laser treatment in wild-type mice; 


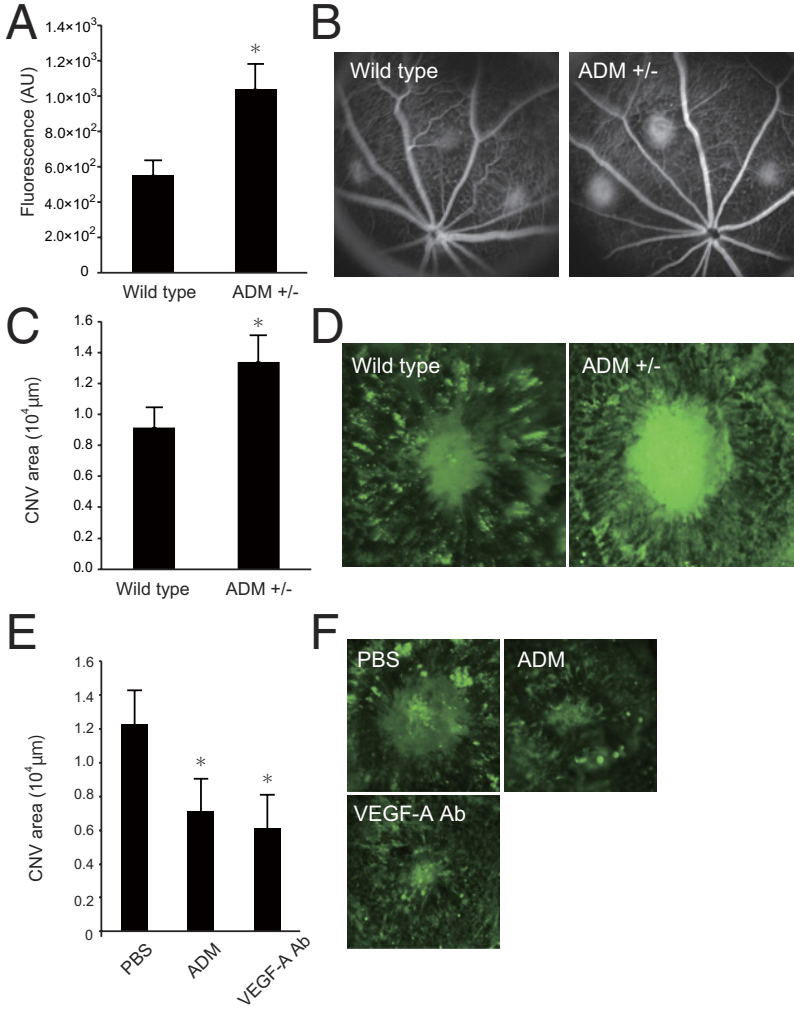

Figure 2. Pathological leakage representing CNV formation 7 days after laser photocoagulation. Large and diffuse areas of leakage were observed in $A D M^{+/-}$mice in comparison with wild-type mice. $\mathbf{A}$ and $\mathbf{B}$ : Fluorescein isothiocyanate dextran angiography. $\mathbf{C}$ and D: Flat mount. $n=12$ for all ${ }^{*} P<0.05$. E and $\mathbf{F}: \mathrm{ADM}$ significantly reduced the CNV volume, and this effect was almost equal to VEGF-A antibody. $n=8$ for all. ${ }^{*} P<0.05$

and the results showed that the areas of CNV were smaller in mice that received intraocular ADM administration in comparison with controls. It should be noted that the inhibitory effect of ADM was almost equal to that of VEGF-A antibody (Figure 2, E and F).

Taken together, these data demonstrate that ADM acts to suppress laser-induced CNV.

\section{Effects of ADM on Angiogenesis}

The pathogenesis of CNV consists of inflammation, angiogenesis, and subsequently neovascularization. Several studies have suggested the role of ADM on both angiogenesis and inflammation, ${ }^{58,59}$ and it is possible that the anti-CNV effect of ADM might derive from various components of this cascade. Thus, the expression of VEGF-A, VEGF-B, pro-angiogenic CCR3 ligands including CCL11, CCL24, and CCL26 were first examined in an RPE cell line, D407, stimulated with ADM for 24 hours by real-time RT-PCR. Specifically, the real-time RT-PCR measurements indicated that VEGF-A and -B showed no change in the expression in comparison with vehicletreated cells, under both normoxic and hypoxic conditions (Figure 3, A and B); however, expression of CCL11, CCL24, and CCL26 were not detectable in D407.

Furthermore, in vitro tube formation assay was performed to examine whether HUVECs form capillary-like structures in response to secreted factors from the D407 cells exposed to ADM. The results demonstrated that HUVECs cultured with the conditioned medium of ADMtreated D407 did not inhibit capillary-like tube formation. To further examine whether ADM directly affects tube formation, HUVECs were cultured with conditioned medium, which was collected from non-ADM-treated D407, and ADM was administered immediately before culturing HUVECs. These results also demonstrated that ADM does not directly affect capillary formation. To summarize, the above-described results demonstrated that ADM not only does not affect capillary-like tube formation, but also neither directly acts on vascular endothelial cells nor acts indirectly to affect pro-angiogenic factors through RPE cells (Figure 3, C and D).

\section{ADM Inhibits Macrophage Migration by Modulating CCL2 from RPE}

Another major function of ADM is to modulate immune reaction at inflammation sites. Consequently, the next experiments were performed to investigate the effects of ADM on inflammation. First, we quantified macrophage migration in vivo. In this assay, the number of subretinal
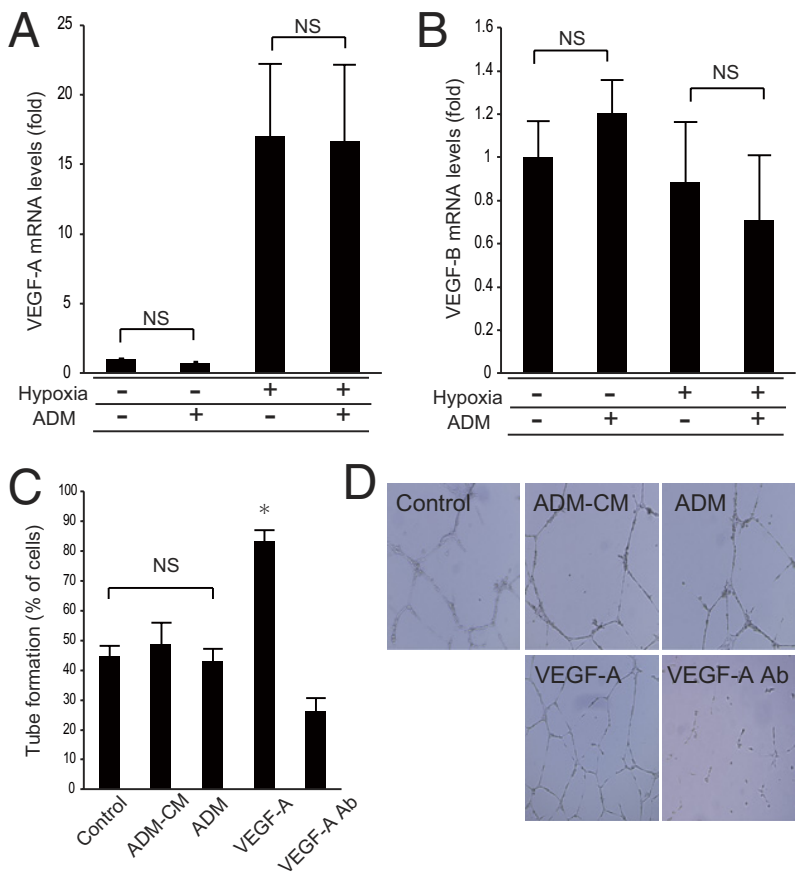

Figure 3. Effect of ADM in RPE and vascular endothelial cells. Expression of VEGF-A (A) and VEGF-B (B) were examined in RPE cells (D407) stimulated with ADM for 24 hours by real-time RT-PCR. The real-time RT-PCR measurements indicated that VEGF-A and -B showed no change in the expression in comparison with vehicle-treated cells. C: In vitro tube formation assay demonstrated that HUVECs cultured with conditioned medium (CM) of ADM treated RPE cells (D407) did not inhibit capillary-like tube formation. Capillary-like tube formation was inhibited by coincubation with human VEGF-A antibody but not with ADM immediately before culturing HUVECs. $n=6$ for all. ${ }^{*} P<0.05$. D: Representative examples of micrographs. Original magnification, $\times 200$ Top left: Cultured with the conditioned medium collected from D 407 cells. Top middle: Cultured with the conditioned medium collected from D407 cells exposed to ADM. Cultured with the conditioned medium collected from D 407 cells and ADM (top right), VEGF-A (bottom left), or VEGF-A antibody (bottom right) just before assay. 
A
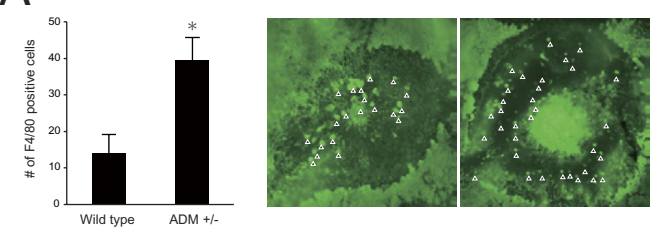

$B$
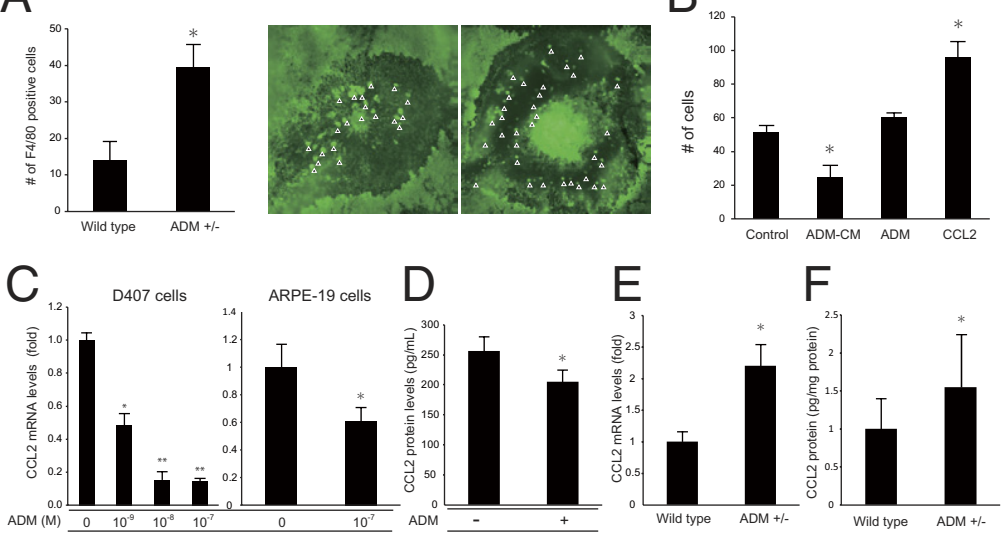

$\mathrm{F}$

F4/80-positive macrophages that were concentrated within the laser burns and around the borders of the laser scars was counted 7 days after laser treatment. Increased infiltration with F4/8-positive cells was observed in $A D M^{+/-}$mice in comparison with wild-type mice (Figure 4A).

Macrophage migration was investigated using in vitro macrophage migration assay in response to ADM or to secreted factors from D407. The results demonstrated that ADM does not directly inhibit macrophage migration. On the other hand, however, when D407 was cultured with ADM and used as conditioned medium, macrophage migration was inhibited significantly, suggesting that ADM mediates indirect inhibition of macrophage migration through modulating the expression of factor(s) from RPE (Figure 4B).

Previous studies have suggested a link between complement cascade and an important chemoattractant in CNV, ie, C-C motif chemokines, especially CCL2. ${ }^{60-62}$ These results led to an investigation in the present study as to whether CCL2 secreted from RPE is modulated by ADM. Real-time PCR measurements demonstrated that CCL2 mRNA was significantly inhibited after ADM treatment in a dose-dependent manner, in both D407 and ARPE19 cells (Figure 4C). Enzyme-linked immunosorbent assay analysis also demonstrated the decreased expression of CCL2 protein from RPE cells (Figure 4D). In addition, the expression of CCL2 mRNA in RPE/choroid from $\mathrm{ADM}^{+/-}$mice and wild-type mice was examined. Expression of CCL2 was increased in $A D M^{+/-}$mice at both the mRNA and protein levels (Figures 4, E and F), corroborating the results from in vitro experiments. No difference in VEGF-A expression between $A D M^{+/-}$mice and wild-type mice (data not shown) was detected. In addition, the CNV lesion was evaluated in CCL2 ${ }^{-1-}$ mice after intravitreous ADM administration (Figure 5) that demonstrated that inhibitory effects of ADM on CNV formation were abrogated in $C C L 2^{-1-}$ mice, suggesting that ADM inhibits choroidal neovascularization mainly by modulating the expression of CCL2 from RPE/choroid.

\section{Discussion}

The current study demonstrated that expression of ADM was significantly increased after laser treatment in wild-
Figure 4. ADM modulates macrophage migration. A: Subretinal macrophages were counted 7 days after $\mathrm{CNV}$ induction. Macrophages were stained with F4/80. Increased accumulation with $\mathrm{F} 4 / 80$-positive cells was observed especially in $A D M^{+/-}$mice in comparison with wild-type mice. $n=6$. ${ }^{*} P<0.05$. Arrowheads indicate $\mathrm{F} 4 / 80$-stained macrophages. B: In vitro macrophage migration assay. Number of macrophages decreased when RPE cells (D407) were cultured with ADM and used as conditioned medium in comparison without ADM. $n=4$ for all. ${ }^{*} P<0.05$. CCL2 was used as positive control. C: RT-PCR measurements indicated CCL2 was significantly inhibited after ADM treatment in a dose-dependent manner in comparison with vehicle-treated cells in two types of RPE cell lines: D407 and ARPE 19. $n=$ 4 for all. ${ }^{*} P<0.05$ and ${ }^{* *} P<0.01$. D: Enzyme-linked immunosorbent assay analysis also demonstrated the decreased expression of CCL2 protein from RPE cells. $n=8$. ${ }^{*} P<0.05$. E and F: Expression of CCL2 was increased in $A D M^{+/-}$mice at both mRNA (E) and protein levels $(\mathbf{F}) . n=8$ for all. ${ }^{*} P<0.05$ type mice. Human ADM is a 52-amino acid peptide originally isolated from human pheochromocytoma. ${ }^{63,64}$ ADM has been detected in plasma and other biological fluids from healthy humans and may behave as a circulating hormone. ${ }^{65-67}$ ADM belongs to the calcitonin gene peptide superfamily based on its slight homology with calcitonin gene-related peptide (CGRP) and amylin. ${ }^{68,69}$ ADM has important effects in vascular tone and permeability and promotes vasodilation. ${ }^{70,71}$ Previous studies clarified that ADM is upregulated in retinal neovascularization and hypoxic retina in mice ${ }^{72,73}$ and in Ndph-knockout mice, a knockout mouse model for Norrie disease. ${ }^{74}$ Upregulation was also noted in RPE cells in a clinically relevant in vitro model of substrate advanced glycation-end product (AGE) accumulation and hypoxic condition. ${ }^{75,76}$ These studies, together with the current results, support a role for ADM on retinal and choroidal neovascularization and possibly on the pathogenesis of AMD. Thus, an important issue for future clinical research is to address whether ADM is upregulated in AMD patients.

The present data clearly demonstrate that reduced expression of ADM leads to the aggravation of CNV, whereas exogenous administration of ADM suppresses laser-induced CNV. Some studies demonstrated that ADM is also a potent angiogenic molecule. These studies described the angiogenic effects of ADM to direct stimulation of endothelial cell proliferation and protection of endothelial cells from apoptosis. ${ }^{77-80}$ The current study, however, failed to demonstrate any direct angiogenic function of ADM. Thus, this angiogenic effect of ADM needs to be clarified in further studies. Recent investigations have determined that ADM signaling is necessary for murine lymphatic vascular development. Mice in
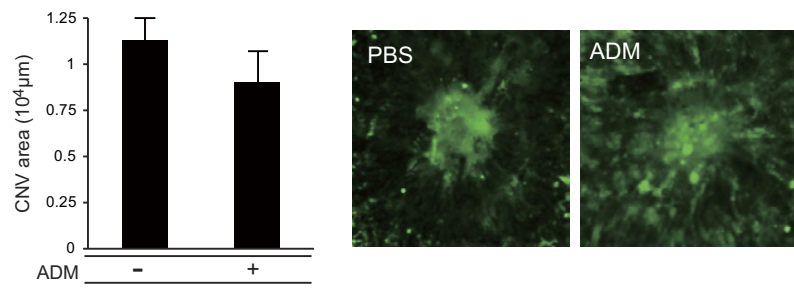

Figure 5. Effect of CCL2 in ADM-mediated CNV inhibition. Inhibitory effects of $\mathrm{ADM}$ on $\mathrm{CNV}$ formation were abrogated in $\mathrm{CCL}^{-1-}$ mice. $n=8 . P=0.304$. 
which ADM has been genetically deleted develop cutaneous edema midgestational lethality due to a defect in lymphatic vessel growth and a cardiovascular defect. $^{81,82}$ Thus, ADM also affects lymphatic vasculature, and the conflicting results of the current study and the previous studies may be reconciled by the fact that choroidal vasculatures lack lymph vessels and most previous studies used models in which both lympho- and angiogenesis was ongoing. ${ }^{82-85}$ Further studies are needed to clarify to the molecular mechanism underlying these conflicting results.

The present study results suggest that the main mechanism of CNV inhibition with administration of ADM is mediated thorough CCL2. A previous study demonstrated that ADM enhanced CFH-mediated cleavage of C3b via factor $I^{86,87}$ Several lines of evidence support that the inactive derivative iC3b binds to CR3 and modulates the production of CCL2. It is well known that C3 has been found in drusen and choroidal tissue, and some reports have shown that C3 was also expressed in RPE cells. ${ }^{88}$ These data lead us to analyze whether ADM modulates iC3b expression. In this study, iC3b was not detected in the RPE cell line (D407) (data not shown), ${ }^{60}$ suggesting that it is unlikely that $\mathrm{ADM}$ regulates the expression of CCL2 through acting on the complement pathway.

Accumulating evidence suggests that there is a relationship between macrophage accumulation and neovascular AMD; however, previous studies have presented conflicting results regarding the role of macrophage on CNV. Although a previous study ${ }^{14}$ observed spontaneous CNV in $\mathrm{CCL}^{-1-}$ and $\mathrm{CCR}^{-1-}$ mice, AMD-like lesion is observed only in senescence. One study ${ }^{89}$ showed reduced laser-induced $\mathrm{CNV}$ lesion size in $\mathrm{CCL}^{-1-}$ mice, and another study ${ }^{90}$ reported that the size of laser-induced CNV were reduced with concomitant reduction in the number of ocular-infiltrating macrophages in $\mathrm{CCR}^{-I-}$ mice. In contrast, other studies have demonstrated that macrophage inhibits laser-induced CNV, and have suggested that one possible explanation for these conflicting findings is a dual role of macrophages. ${ }^{91,92}$ The current results support the pro-angiogenic function of macrophages in CNV; however, diverse subsets of macrophages may have different roles in the pathogenesis of CNV.

The current in vitro experiments demonstrated that ADM did not inhibit VEGF-A expression directly, and showed that there is no difference between VEGF-A expression in $A D M^{+/-}$mice and wild-type mice. However, it is generally accepted that macrophages themselves are a source of VEGF-A and act to stimulate angiogenesis. ${ }^{90,93,94}$ Thus, current data do not completely rule out the possibility that intravitreal administration of ADM may result in the reduction of locally produced VEGF-A by macrophage.

In conclusion, the present study demonstrates that blocking CCL2 with the administration of ADM inhibits macrophage migration and leads to the suppression of laser-induced CNV in an animal model. Although antiVEGF therapy is the main choice of treatment for neovascular AMD, there is concern about some of the side effects, and some cases are refractory to the current anti-VEGF therapy $37,38,42-44,49$. Our study provides evi- dence that demonstrates the potential of specific targeting of ADM for future therapies of CNV due to AMD. Studies are needed to further characterize the role of ADM in reducing CNV. In addition, the safety of intraocular administration of ADM remains to be determined. However, ADM hopefully will become an alternative treatment target for CNV treatment.

\section{Acknowledgments}

We thank Yasuko Kuwabara and Fujie Takeda for their excellent technical assistance, Hiroko Meguro for the microarray analysis, and Yasuo Ikeda and Toshio Hisatomi for their helpful comments on transmission electron micrography.

\section{References}

1. Ferris FL, Fine SL, Hyman L: Age-related macular degeneration and blindness due to neovascular maculopathy. Arch Ophthalmol 1984, 102:1640-1642

2. Klein R, Wang Q, Klein BE, Moss SE, Meuer SM: The relationship of age-related maculopathy, cataract, and glaucoma to visual acuity. Invest Ophthalmol Vis Sci 1995, 36:182-191

3. Gass JD: Drusen and disciform macular detachment and degeneration. Trans Am Ophthalmol Soc 1972, 70:409-436

4. Bressler SB, Maguire MG, Bressler NM, Fine SL: Relationship of drusen and abnormalities of the retinal pigment epithelium to the prognosis of neovascular macular degeneration. The Macular Photocoagulation Study Group. Arch Ophthalmol 1990, 108:1442-1447

5. Anderson DH, Mullins RF, Hageman GS, Johnson LV: A role for local inflammation in the formation of drusen in the aging eye. Am $J$ Ophthalmol 2002, 134:411-431

6. Johnson PT, Lewis GP, Talaga KC, Brown MN, Kappel PJ, Fisher SK Anderson $\mathrm{DH}$, Johnson LV: Drusen-associated degeneration in the retina. Invest Ophthalmol Vis Sci 2003, 44:4481-4488

7. Yu Y, Reynolds R, Fagerness J, Rosner B, Daly MJ, Seddon JM: Association of variants in the LIPC and ABCA1 genes with intermediate and large drusen and advanced age-related macular degeneration. Invest Ophthalmol Vis Sci 2011, 52:4663-4670

8. Nilsson SE, Sundelin SP, Wihlmark U, Brunk UT: Aging of cultured retinal pigment epithelial cells: oxidative reactions, lipofuscin formation and blue light damage. Doc Ophthalmol 2003, 106:13-16

9. Wihlmark U, Wrigstad A, Roberg K, Nilsson SE, Brunk UT: Lipofuscin accumulation in cultured retinal pigment epithelial cells causes enhanced sensitivity to blue light irradiation. Free Radic Biol Med 1997, 22:1229-1234

10. Crabb JW, Miyagi M, Gu X, Shadrach K, West KA, Sakaguchi H, Kamei M, Hasan A, Yan L, Rayborn ME, Salomon RG, Hollyfield JG: Drusen proteome analysis: an approach to the etiology of age-related macular degeneration. Proc Natl Acad Sci USA 2002, 99:1468214687

11. Yoshida T, Ohno-Matsui K, Ichinose S, Sato T, Iwata N, Saido TC Hisatomi T, Mochizuki M, Morita I: The potential role of amyloid beta in the pathogenesis of age-related macular degeneration. J Clin Invest 2005, 115:2793-2800

12. Wang J, Ohno-Matsui K, Yoshida T, Kojima A, Shimada N, Nakahama K, Safranova O, Iwata N, Saido TC, Mochizuki M, Morita I: Altered function of factor I caused by amyloid beta: implication for pathogenesis of age-related macular degeneration from drusen. J Immunol 2008, 181:712-720

13. Wang J, Ohno-Matsui K, Yoshida T, Shimada N, Ichinose S, Sato T, Mochizuki M, Morita I: Amyloid-beta up-regulates complement factor $B$ in retinal pigment epithelial cells through cytokines released from recruited macrophages/microglia: another mechanism of complement activation in age-related macular degeneration. J Cell Physiol 2009, 220:119-128

14. Ambati J, Anand A, Fernandez S, Sakurai E, Lynn BC, Kuziel WA, Rollins BJ, Ambati BK: An animal model of age-related macular 
degeneration in senescent Ccl-2- or Ccr-2-deficient mice. Nat Med 2003, 9:1390-1397

15. Sakurai E, Anand A, Ambati BK, van Rooijen N, Ambati J: Macrophage depletion inhibits experimental choroidal neovascularization. Invest Ophthalmol Vis Sci 2003, 44:3578-3585

16. Yamada K, Sakurai E, Itaya M, Yamasaki S, Ogura Y: Inhibition of laser-induced choroidal neovascularization by atorvastatin by downregulation of monocyte chemotactic protein-1 synthesis in mice. Invest Ophthalmol Vis Sci 2007, 48:1839-1843

17. Nozaki M, Raisler BJ, Sakurai E, Sarma JV, Barnum SR, Lambris JD, Chen Y, Zhang K, Ambati BK, Baffi JZ, Ambati J: Drusen complement components $\mathrm{C} 3 \mathrm{a}$ and $\mathrm{C} 5 \mathrm{a}$ promote choroidal neovascularization. Proc Natl Acad Sci USA 2006, 103:2328-2333

18. Johnson LV, Leitner WP, Staples MK, Anderson DH: Complement activation and inflammatory processes in Drusen formation and age related macular degeneration. Exp Eye Res 2001, 73:887-896

19. Bora PS, Sohn JH, Cruz JM, Jha P, Nishihori H, Wang Y, Kaliappan S, Kaplan HJ, Bora NS: Role of complement and complement membrane attack complex in laser-induced choroidal neovascularization. J Immunol 2005, 174:491-497

20. Smith W, Mitchell P, Leeder SR: Smoking and age-related maculopathy. The Blue Mountains Eye Study. Arch Ophthalmol 1996, 114: $1518-1523$

21. Vingerling JR, Hofman A, Grobbee DE, DE Jong PT: Age-related macular degeneration and smoking. The Rotterdam Study. Arch Ophthalmol 1996, 114:1193-1196

22. Wang L, Clark ME, Crossman DK, Kojima K, Messinger JD, Mobley JA, Curcio CA: Abundant lipid and protein components of drusen. PLoS One 2010, 5:e10329

23. Edwards AO, Ritter R, Abel KJ, Manning A, Panhuysen C, Farrer LA: Complement factor $\mathrm{H}$ polymorphism and age-related macular degeneration. Science 2005, 308:421-424

24. Hageman GS, Anderson DH, Johnson LV, Hancox LS, Taiber AJ, Hardisty LI, Hageman JL, Stockman HA, Borchardt JD, Gehrs KM, Smith RJ, Silvestri G, Russell SR, Klaver CC, Barbazetto I, Chang S, Yannuzzi LA, Barile GR, Merriam JC, Smith RT, Olsh AK, Bergeron J, Zernant J, Merriam JE, Gold B, Dean M, Allikmets R: A common haplotype in the complement regulatory gene factor $\mathrm{H}(\mathrm{HF} 1 / \mathrm{CFH})$ predisposes individuals to age-related macular degeneration. Proc Natl Acad Sci USA 2005, 102:7227-7232

25. Haines JL, Hauser MA, Schmidt S, Scott WK, Olson LM, Gallins P, Spencer KL, Kwan SY, Noureddine M, Gilbert JR, Schnetz-Boutaud N, Agarwal A, Postel EA, Pericak-Vance MA: Complement factor $\mathrm{H}$ variant increases the risk of age-related macular degeneration. Science 2005, 308:419-421

26. Klein RJ, Zeiss C, Chew EY, Tsai JY, Sackler RS, Haynes C, Henning AK, SanGiovanni JP, Mane SM, Mayne ST, Bracken MB, Ferris FL, Ott J, Barnstable C, Hoh J: Complement factor $\mathrm{H}$ polymorphism in agerelated macular degeneration. Science 2005, 308:385-389

27. Johnson PT, Betts KE, Radeke MJ, Hageman GS, Anderson DH, Johnson LV: Individuals homozygous for the age-related macular degeneration risk-conferring variant of complement factor $\mathrm{H}$ have elevated levels of CRP in the choroid. Proc Natl Acad Sci USA 2006, 103:17456-17461

28. Lommatzsch A, Hermans P, Weber B, Pauleikhoff D: Complement factor $\mathrm{H}$ variant $\mathrm{Y} 402 \mathrm{H}$ and basal laminar deposits in exudative age-related macular degeneration. Graefes Arch Clin Exp Ophthalmol 2007, 245:1713-1716

29. Kim YH, He S, Kase S, Kitamura M, Ryan SJ, Hinton DR: Regulated secretion of complement factor $\mathrm{H}$ by RPE and its role in RPE migration. Graefes Arch Clin Exp Ophthalmol 2009, 247:651-659

30. Wu Z, Lauer TW, Sick A, Hackett SF, Campochiaro PA: Oxidative stress modulates complement factor $\mathrm{H}$ expression in retinal pigmented epithelial cells by acetylation of FOXO3. J Biol Chem 2007, 282.22414-22425

31. Chen M, Forrester JV, Xu H: Synthesis of complement factor $\mathrm{H}$ by retinal pigment epithelial cells is down-regulated by oxidized photoreceptor outer segments. Exp Eye Res 2007, 84:635-645

32. Bora NS, Kaliappan S, Jha $P, X u$ Q, Sivasankar B, Harris CL, Morgan BP, Bora PS: CD59, a complement regulatory protein, controls choroidal neovascularization in a mouse model of wet-type age-related macular degeneration. J Immunol 2007, 178:1783-1790
33. Leung DW, Cachianes G, Kuang WJ, Goeddel DV, Ferrara N: Vascular endothelial growth factor is a secreted angiogenic mitogen. Science 1989, 246:1306-1309

34. Otani A, Takagi H, Oh H, Koyama S, Ogura Y, Matumura M, Honda Y: Vascular endothelial growth factor family and receptor expression in human choroidal neovascular membranes. Microvasc Res 2002, 64: 162-169

35. Gragoudas ES, Adamis AP, Cunningham ET, Jr., Feinsod M, Guyer DR: Pegaptanib for neovascular age-related macular degeneration. N Engl J Med 2004, 351:2805-2816

36. Brown DM, Kaiser PK, Michels M, Soubrane G, Heier JS, Kim RY, Sy JP, Schneider S: Ranibizumab versus verteporfin for neovascular age-related macular degeneration. N Engl J Med 2006, 355:1432-1444

37. Rosenfeld PJ, Brown DM, Heier JS, Boyer DS, Kaiser PK, Chung CY Kim RY: Ranibizumab for neovascular age-related macular degeneration. N Engl J Med 2006, 355:1419-1431

38. Nishijima K, Ng YS, Zhong L, Bradley J, Schubert W, Jo N, Akita J, Samuelsson SJ, Robinson GS, Adamis AP, Shima DT: Vascular endothelial growth factor-A is a survival factor for retinal neurons and a critical neuroprotectant during the adaptive response to ischemic injury. Am J Pathol 2007, 171:53-67

39. Hanahan D: Signaling vascular morphogenesis and maintenance. Science 1997, 277:48-50

40. Yang X, Cepko CL: Flk-1, a receptor for vascular endothelial growth factor (VEGF), is expressed by retinal progenitor cells. J Neurosci 1996, 16:6089-6099

41. Kim I, Ryan AM, Rohan R, Amano S, Agular S, Miller JW, Adamis AP: Constitutive expression of VEGF, VEGFR-1, and VEGFR-2 in normal eyes. Invest Ophthalmol Vis Sci 1999, 40:2115-2121

42. Kaempf S, Johnen S, Salz AK, Weinberger A, Walter P, Thumann G Effects of bevacizumab (Avastin) on retinal cells in organotypic culture. Invest Ophthalmol Vis Sci 2008, 49:3164-3171

43. Brar VS, Sharma RK, Murthy RK, Chalam KV: Bevacizumab neutralizes the protective effect of vascular endothelial growth factor on retinal ganglion cells. Mol Vis 2010, 16:1848-1853

44. Saint-Geniez M, Maharaj AS, Walshe TE, Tucker BA, Sekiyama E, Kurihara T, Darland DC, Young MJ, D'Amore PA: Endogenous VEGF is required for visual function: evidence for a survival role on Muller cells and photoreceptors. PLoS One 2008, 3:e3554

45. Sassa Y, Hata Y: Antiangiogenic drugs in the management of ocular diseases: focus on antivascular endothelial growth factor. Clin Ophthalmol 2010, 4:275-283

46. Iriyama A, Chen YN, Tamaki Y, Yanagi Y: Effect of anti-VEGF antibody on retinal ganglion cells in rats. $\mathrm{Br} \mathrm{J}$ Ophthalmol 2007, 91:1230-1233

47. Guo B, Wang Y, Hui Y, Yang X, Fan Q: Effects of anti-VEGF agents on rat retinal Muller glial cells. Mol Vis 2010, 16:793-799

48. Chalam KV, Agarwal S, Brar VS, Murthy RK, Sharma RK: Evaluation of cytotoxic effects of bevacizumab on human corneal cells. Cornea 2009, 28:328-333

49. Stangos AN, Gandhi JS, Nair-Sahni J, Heimann H, Pournaras CJ, Harding SP: Polypoidal choroidal vasculopathy masquerading as neovascular age-related macular degeneration refractory to ranibizumab. Am J Ophthalmol 2010, 150:666-673

50. Shindo T, Kurihara $Y$, Nishimatsu $H$, Moriyama N, Kakoki M, Wang $Y$, Imai $Y$, Ebihara A, Kuwaki T, Ju KH, Minamino N, Kangawa K, Ishikawa T, Fukuda M, Akimoto $\mathrm{Y}$, Kawakami $\mathrm{H}$, Imai $\mathrm{T}$, Morita $\mathrm{H}$, Yazaki $Y$, Nagai R, Hirata $Y$, Kurihara $H$ : Vascular abnormalities and elevated blood pressure in mice lacking adrenomedullin gene. Circulation 2001, 104:1964-1971

51. Takahashi H, Obata R, Tamaki Y: A novel vascular endothelial growth factor receptor 2 inhibitor. SU11248, suppresses choroidal neovascularization in vivo. J Ocul Pharmacol Ther 2006, 22:213-218

52. Ufret-Vincenty RL, Aredo B, Liu X, McMahon A, Chen PW, Sun H, Niederkorn JY, Kedzierski W: Transgenic mice expressing variants of complement factor $\mathrm{H}$ develop AMD-like retinal findings. Invest Ophthalmol Vis Sci 2010, 51:5878-5887

53. Vierkotten S, Muether PS, Fauser S: Overexpression of HTRA1 leads to ultrastructural changes in the elastic layer of Bruch's membrane via cleavage of extracellular matrix components. PLoS One 2011, 6:e22959

54. Takezawa S, Yokoyama A, Okada M, Fujiki R, Iriyama A, Yanagi Y, Ito H, Takada I, Kishimoto M, Miyajima A, Takeyama K, Umesono K, Kitagawa H, Kato S: A cell cycle-dependent co-repressor mediates 
photoreceptor cell-specific nuclear receptor function. EMBO J 2007 , 26:764-774

55. Kishimoto S, Gokoh M, Oka S, Muramatsu M, Kajiwara T, Waku K, Sugiura $\mathrm{T}$ : 2-arachidonoylglycerol induces the migration of $\mathrm{HL}-60$ cells differentiated into macrophage-like cells and human periphera blood monocytes through the cannabinoid CB2 receptor-dependent mechanism. J Biol Chem 2003, 278:24469-24475

56. Ishida N, Hayashi K, Hattori A, Yogo K, Kimura T, Takeya T: CCR1 acts downstream of NFAT2 in osteoclastogenesis and enhances cell migration. J Bone Miner Res 2006, 21:48-57

57. Schmidt CQ, Herbert AP, Hocking HG, Uhrin D, Barlow PN: Translational mini-review series on complement factor $\mathrm{H}$ : structural and functional correlations for factor $\mathrm{H}$. Clin Exp Immunol 2008, 151:14-24

58. limuro S, Shindo T, Moriyama N, Amaki T, Niu P, Takeda N, Iwata H, Zhang Y, Ebihara A, Nagai R: Angiogenic effects of adrenomedullin in ischemia and tumor growth. Circ Res 2004, 95:415-423

59. Yanagawa B, Kataoka M, Ohnishi S, Kodama M, Tanaka K, Miyahara Y, Ishibashi-Ueda H, Aizawa Y, Kangawa K, Nagaya N: Infusion of adrenomedullin improves acute myocarditis via attenuation of myocardial inflammation and edema. Cardiovasc Res 2007, 76:110-118

60. Trinidad AG, de la Puerta ML, Fernandez N, Bayon Y, Crespo MS, Alonso A: Coupling of C3bi to IgG inhibits the tyrosine phosphorylation signaling cascade downstream Syk and reduces cytokine induction in monocytes. J Leukoc Biol 2006, 79:1073-1082

61. Farina C, Aloisi F, Meinl E: Astrocytes are active players in cerebral innate immunity. Trends Immunol 2007, 28:138-145

62. Venkatesha RT, Berla Thangam E, Zaidi AK, Ali H: Distinct regulation of C3a-induced MCP-1/CCL2 and RANTES/CCL5 production in human mast cells by extracellular signal regulated kinase and PI3 kinase. Mol Immunol 2005, 42:581-587

63. Kitamura K, Kangawa K, Kawamoto M, Ichiki Y, Nakamura S, Matsuo $\mathrm{H}$, Eto T: Adrenomedullin: a novel hypotensive peptide isolated from human pheochromocytoma. Biochem Biophys Res Commun 1993, 192:553-560

64. Kitamura K, Sakata J, Kangawa K, Kojima M, Matsuo H, Eto T: Cloning and characterization of cDNA encoding a precursor for human adrenomedullin. Biochem Biophys Res Commun 1993, 194: 720-725

65. Ichiki Y, Kitamura K, Kangawa K, Kawamoto M, Matsuo H, Eto T: Distribution and characterization of immunoreactive adrenomedullin in porcine tissue, and isolation of adrenomedullin [26-52] and adrenomedullin [34-52] from porcine duodenum. J Biochem 1995, 118 $765-770$

66. Sato K, Hirata Y, Imai T, Iwashina M, Marumo F: Characterization of immunoreactive adrenomedullin in human plasma and urine. Life Sci 1995, 57:189-194

67. Di lorio R, Marinoni E, Scavo D, Letizia C, Cosmi EV: Adrenomedullin in pregnancy. Lancet 1997, 349:328

68. DeWitt BJ, Cheng DY, Caminiti GN, Nossaman BD, Coy DH, Murphy WA, Kadowitz PJ: Comparison of responses to adrenomedullin and calcitonin gene-related peptide in the pulmonary vascular bed of the cat. Eur J Pharmacol 1994, 257:303-306

69. Osajima A, Mutoh Y, Uezono Y, Kawamura M, Izumi F, Takasugi M, Kuroiwa A: Adrenomedullin increases cyclic AMP more potently than CGRP and amylin in rat renal tubular basolateral membranes. Life Sci 1995, 57:457-462

70. Hinson JP, Kapas S, Smith DM: Adrenomedullin, a multifunctional regulatory peptide. Endocr Rev 2000, 21:138-167

71. Martinez A, Cuttitta F. Teitelman G: Expression pattern for adrenomedullin during pancreatic development in the rat reveals a common precursor with other endocrine cell types. Cell Tissue Res 1998, 293:95-100

72. Recchia FM, Xu L, Penn JS, Boone B, Dexheimer PJ: Identification of genes and pathways involved in retinal neovascularization by microarray analysis of two animal models of retinal angiogenesis. Invest Ophthalmol Vis Sci 2010, 51:1098-1105

73. Thiersch M, Raffelsberger W, Frigg R, Samardzija M, Wenzel A, Poch $\mathrm{O}$, Grimm C: Analysis of the retinal gene expression profile after hypoxic preconditioning identifies candidate genes for neuroprotection. BMC Genomics 2008, 9:73

74. Schafer NF, Luhmann UF, Feil S, Berger W: Differential gene expression in Ndph-knockout mice in retinal development. Invest Ophthalmol Vis Sci 2009, 50:906-916
75. Glenn JV, Mahaffy H, Wu K, Smith G, Nagai R, Simpson DA, Boulton ME, Stitt AW: Advanced glycation end product (AGE) accumulation on Bruch's membrane: links to age-related RPE dysfunction. Invest Ophthalmol Vis Sci 2009, 50:441-451

76. Udono T, Takahashi K, Nakayama M, Yoshinoya A, Totsune K, Murakami O, Durlu YK, Tamai M, Shibahara S: Induction of adrenomedullin by hypoxia in cultured retinal pigment epithelial cells. Invest Ophthalmol Vis Sci 2001, 42:1080-1086

77. Kim SM, Kim JY, Lee S, Park JH: Adrenomedullin protects against hypoxia/reoxygenation-induced cell death by suppression of reactive oxygen species via thiol redox systems. FEBS Lett 2010, 584:213-218

78. Belloni AS, Guidolin D, Ceretta S, Bova S, Nussdorfer GG: Acute effects of endothelins on endogenous adrenomedullin system in the rat heart: immunocytochemical and autoradiographic studies. Int $J$ Mol Med 2004, 13:669-674

79. Belloni AS, Guidolin D, Ceretta S, Bova S, Nussdorfer GG: Acute effect of ischemia on adrenomedullin immunoreactivity in the rat heart: an immunocytochemical study. Int J Mol Med 2004, 14:71-73

80. Guidolin D, Albertin G, Spinazzi R, Sorato E, Mascarin A, Cavallo D, Antonello M, Ribatti D: Adrenomedullin stimulates angiogenic response in cultured human vascular endothelial cells: involvement of the vascular endothelial growth factor receptor 2. Peptides 2008, 29:2013-2023

81. Fritz-Six KL, Dunworth WP, Li M, Caron KM: Adrenomedullin signaling is necessary for murine lymphatic vascular development. J Clin Invest 2008, 118:40-50

82. Dunworth WP, Fritz-Six KL, Caron KM: Adrenomedullin stabilizes the lymphatic endothelial barrier in vitro and in vivo. Peptides 2008, 29:2243-2249

83. Fang C, Miguel MA, Avis I, Martinez A, Zudaire E, Cuttitta F: Nonpeptide small molecule regulators of lymphangiogenesis. Lymphat Res Biol 2009, 7:189-196

84. Ribatti D, Nico B, Spinazzi R, Vacca A, Nussdorfer GG: The role of adrenomedullin in angiogenesis. Peptides 2005, 26:1670-1675

85. Nikitenko LL, Smith DM, Bicknell R, Rees MC: Transcriptional regulation of the CRLR gene in human microvascular endothelial cells by hypoxia. FASEB J 2003, 17:1499-1501

86. Pio R, Martinez A, Unsworth EJ, Kowalak JA, Bengoechea JA, Zipfel $\mathrm{PF}$, Elsasser $\mathrm{TH}$, Cuttitta $\mathrm{F}$ : Complement factor $\mathrm{H}$ is a serum-binding protein for adrenomedullin, and the resulting complex modulates the bioactivities of both partners. J Biol Chem 2001, 276:12292-12300

87. Martinez A, Pio R, Lopez J, Cuttitta F: Expression of the adrenomedullin binding protein, complement factor $\mathrm{H}$, in the pancreas and its physiological impact on insulin secretion. J Endocrinol 2001, 170: 503-511

88. Khandhadia S, Cipriani V, Yates JR, Lotery AJ: Age-related macular degeneration and the complement system. Immunobiology 2011, 217:217-146

89. Luhmann UF, Robbie S, Munro PM, Barker SE, Duran Y, Luong V, Fitzke FW, Bainbridge JW, Ali RR, MacLaren RE: The drusenlike phenotype in aging Ccl2-knockout mice is caused by an accelerated accumulation of swollen autofluorescent subretinal macrophages. Invest Ophthalmol Vis Sci 2009, 50:5934-5943

90. Tsutsumi C, Sonoda KH, Egashira K, Qiao H, Hisatomi T, Nakao S, Ishibashi M, Charo IF, Sakamoto T, Murata T, Ishibashi T: The critical role of ocular-infiltrating macrophages in the development of choroidal neovascularization. J Leukoc Biol 2003, 74:25-32

91. Kelly J, Ali Khan A, Yin J, Ferguson TA, Apte RS: Senescence regulates macrophage activation and angiogenic fate at sites of tissue injury in mice. J Clin Invest 2007, 117:3421-3426

92. Apte RS, Richter J, Herndon J, Ferguson TA: Macrophages inhibit neovascularization in a murine model of age-related macular degeneration. PLoS Med 2006, 3:e310

93. Ishibashi $\mathrm{T}$, Hata $\mathrm{Y}$, Yoshikawa H, Nakagawa K, Sueishi K, Inomata H: Expression of vascular endothelial growth factor in experimental choroidal neovascularization. Graefes Arch Clin Exp Ophthalmol 1997, 235:159-167

94. Yi X, Ogata N, Komada M, Yamamoto C, Takahashi K, Omori K, Uyama M: Vascular endothelial growth factor expression in choroidal neovascularization in rats. Graefes Arch Clin Exp Ophthalmol 1997. 235:313-319 